\title{
Public health investigations required for protecting the population against novel coronaviruses
}

A. Nicoll

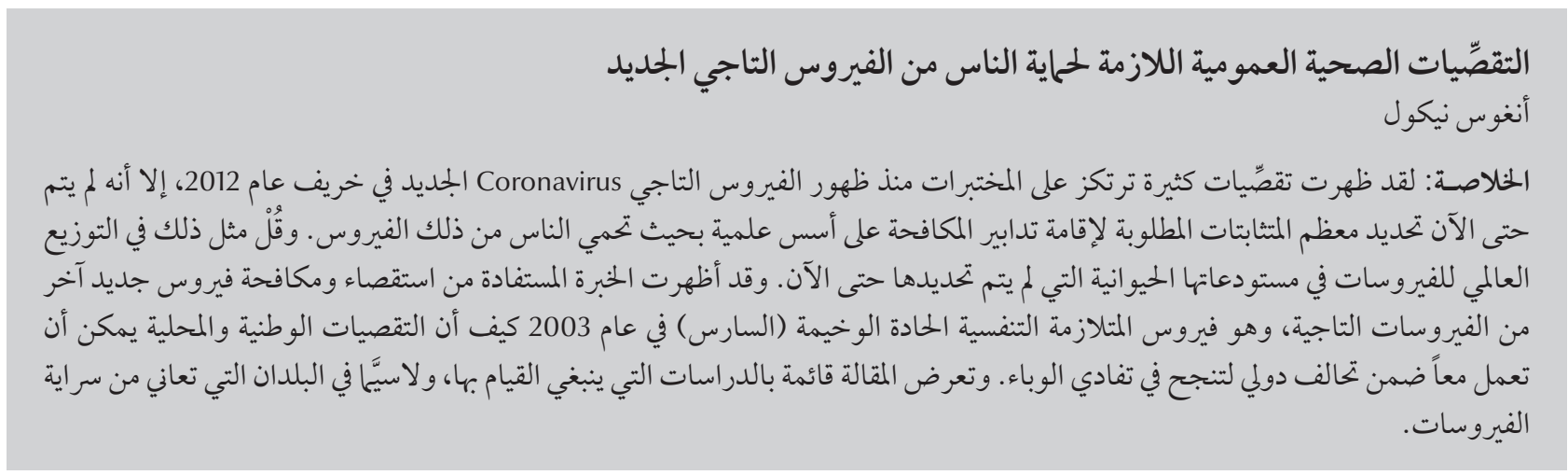

ABSTRACT There have been many laboratory-based investigations since the emergence of the novel coronaviruses in the autumn of 2012, but most of the parameters required for establishing scientifically the control measures that will protect against them have yet to be determined. Equally, the global distribution of the viruses in their animal reservoir has yet to be established. The experience of investigating and controlling another novel coronavirus, SARS, in 2003 shows how national and local investigations can come together as an international coalition and successfully avert epidemics. A menu of studies that need to be undertaken, especially in the countries experiencing transmission, is presented here.

Etudes de santé publique requises pour la protection de la population contre les nouveaux coronavirus

RÉSUMÉ Depuis l'émergence de nouveaux coronavirus pendant l'automne 2012, de nombreuses études ont été menées en laboratoire, mais la plupart des paramètres requis pour l'établissement scientifique de mesures de lutte qui soient capables de protéger contre ces virus restent à définir. De plus, la répartition mondiale de ces virus dans leur réservoir animal doit encore être établie. En 2003, l'expérience de la recherche sur un autre nouveau coronavirus, le syndrome respiratoire aigu sévère, et de la lutte contre ce virus a démontré comment des recherches nationales et locales permettent de mettre en place un front commun au sein d'une coalition internationale et d'éviter efficacement les épidémies. Les études qui doivent être menées, en particulier dans les pays où la transmission est active, sont répertoriées dans le présent article. 


\section{Introduction}

Concerns have been raised globally by the appearance in 2012 of a novel coronavirus $(\mathrm{nCoV})$ causing severe respiratory disease within some countries in the Middle East and in patients transferred for medical care in Europe $[1-3]$. The fact that a significant proportion of the confirmed cases have died and that the cause is a coronavirus of presumed animal origin has revived memories of the severe acute respiratory syndrome (SARS) epidemics of 2003 [3-5]. Patients who survive the initial infection often require prolonged artificial respiratory support (mechanical ventilation or extra corporeal membrane oxygenation), so even a few cases impact significantly on higherlevel clinical services. A case travelling to Europe on a commercial flight and then infecting others indicates how easily the infection might spread internationally, as seen with the SARS coronavirus $[6,7]$.

The purpose of this short communication is to summarize thinking on priorities for surveillance, applied epidemiological studies, and public health research and development activities. The approach taken is to highlight particular questions that need to be answered for the purposes of preventing or treating these infections and diseases - the what and the why of each specific question. This is followed by an explanation of the mechanisms by which each question can be answered (the how) leading to a list of the specific studies required to achieve this.

\section{Controlling and protecting against novel coronaviruses}

The new viruses have been genetically sequenced $[8,9]$. Bats are considered to be the hosts for animal coronaviruses and these novel viruses affecting humans are similar to a number of bat coronaviruses isolated in both the old and the new world [10]. While they bear some relationship to the SARS-CoV virus which caused severe acute respiratory syndrome (SARS), they are also sufficiently different to preclude the assumption that they will behave in the same way as SARS-CoV [9]. Indeed the signature characteristic of SARS outbreaks in humans - super spreading events - have not been described so far $[3,5,7]$. Analytic virological studies of $\mathrm{nCoV}$ have appeared with impressive speed in peer reviewed journals and some of the conclusions reached are concerning $[9,11-13]$. The virus may have the potential to spread in a range of mammalian cells; binds to a receptor that is preserved across a number of species, including humans $[11,13]$; it can also infect and replicate with cytopathic effect in a wide range of cell-lines across various human tissue types and from other species [12]. However virological investigations alone cannot predict how the virus will behave, its pathogenic action or how it should be treated or controlled [14].

At present (April 2013), there is still a lack of much of the information that would be needed to inform on how to control $\mathrm{nCoV}$ infection; prevent initial infections; interrupt any humanto-human transmission; and manage and treat human infections (Table 1).

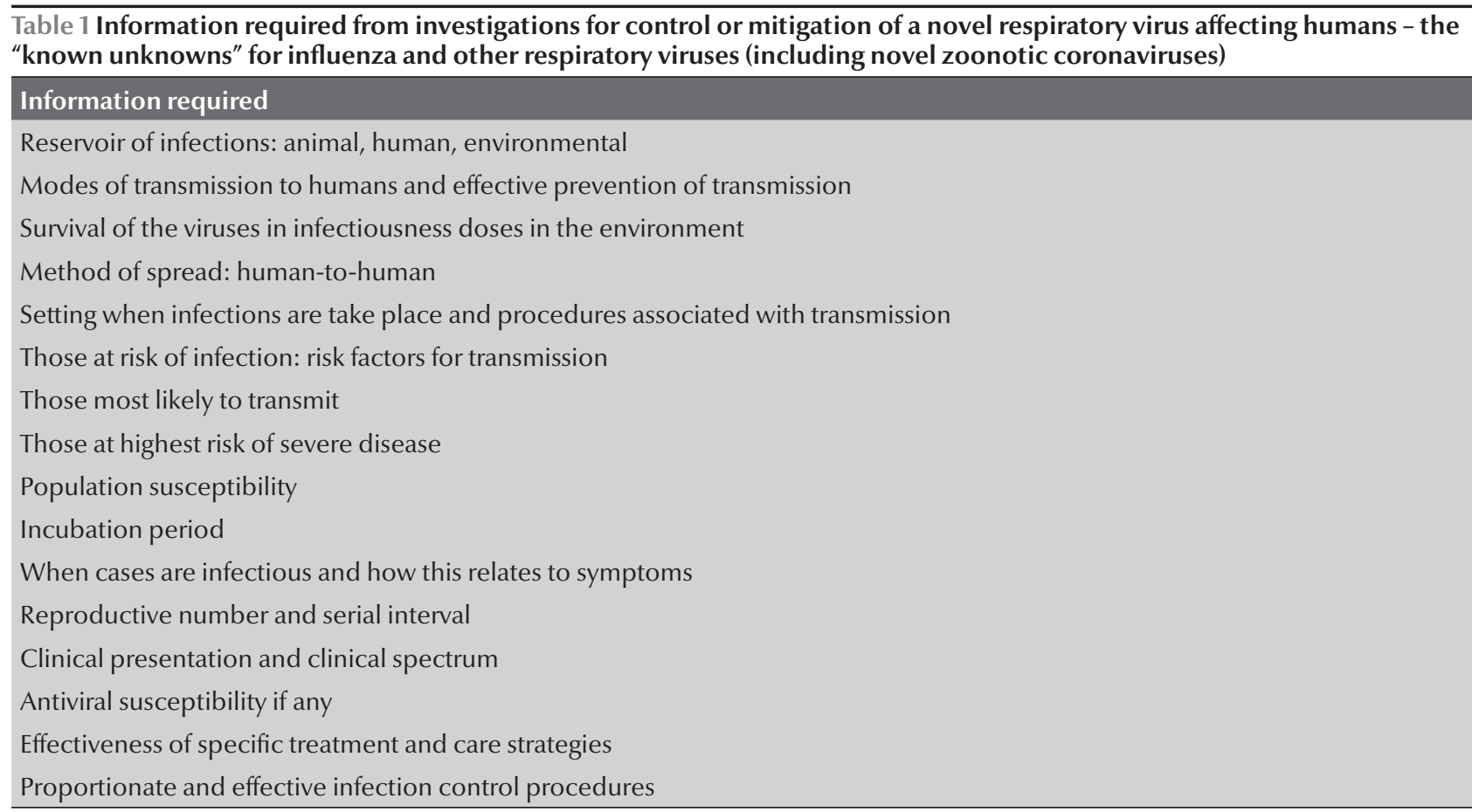


Equally, it is unclear what (and where) the natural and more recent reservoirs of infection are. SARS for example had both a reservoir in bats and an intermediary host in southern China [15]. Similarly, it is unclear whether humans are occasionally being infected outside the Middle East.

It can be argued that the simplest response would be to assume that the parameters for control of the $\mathrm{nCoVs}$ would be the same as those for SARS and apply the same measures. However, these measures cannot be undertaken lightly because some of those which were effective in controlling SARS were resource-intensive and disruptive to societies and, especially, health-care economies [3]; therefore the parameters for control of $\mathrm{nCoV}$ infection need to be determined speedily. This uncertainty and the need for speedy action led the WHO Regional Office for the Eastern Mediterranean to convene a consultation in Cairo in January 2013 attended by the countries experiencing cases in the Middle East and Europe; the relevant European laboratories [the Erasmus Medical Centre, Health Protection Agency (since April 2013 now called Public Health England) and the University of Bonn]; and the public health authorities from Germany and the United Kingdom (Robert Koch Institute and Public Health England, respectively). This ECDC staff member also attended and presented an earlier version of this paper.

Extensive epidemiological investigations have been undertaken around the few cases that have come to $\mathrm{Eu}$ rope. Rapid publications from these are reassuring on transmissibility and appear to contradict some of the more worrying interpretations of the laboratory studies $[6,16,17]$. In Europe the novel viruses are not behaving in the same way as the SARS viruses did in countries outside Europe in 2003 (Table 1)[18]: to date, testing of over 200 close contacts of the first 2 imported cases have not revealed a single transmission (serological results are pending for the United Kingdom contacts) $[16,17$,$] . Yet a third$ case who travelled on a commercial flight resulted in unsustained humanto-human transmission after arrival in the United Kingdom. There were 2 secondary transmissions: one in a family setting, the other a nosocomial infection in hospital $[1,6]$. This same cluster of 3 cases included the first confirmed mild case and another case with dual infection of the new virus and a seasonal influenza virus [6].

It would be unwise to base global guidance on the experience in a single country or region, even in an area as large as Europe. One of the notable features of the SARS coronaviruses in 2003 was the diversity of experience which arose seemingly by chance [7]. While some countries with imported cases had no transmissions, others experienced considerably transmission, often in association with superspreading events $[5,7]$. European Union/European Economic Area countries experienced only 32 probable SARS cases in 2003 ( $0.4 \%$ of the global total), with 1 death and no further transmissions [18]. So far, the experience with the $\mathrm{nCoV}$ in 2012 2013 looks very similar to that with SARS in Europe in 2003 when there were imported confirmed cases but no sustained human-to-human transmission $[1,7,19]$. Hence, the $2012-$ 2013 European data alone do not provide a sufficient basis to conclude that the intense local transmission that happened in Hanoi, Vietnam, Hong Kong, Singapore and Toronto, Canada could not be reproduced with the new coronavirus $[5,7]$.

It is instructive to consider how the measures that were effective in controlling SARS were determined in 2003. Essentially, the scientific basis for these measures (Table 2) was determined by the countries in which infection and transmission took place_-Canada, China, Hong Kong, Singapore, Taiwan and Viet $\mathrm{Nam}$ - working together with WHO. Information from detailed field investigations undertaken around the cases in those countries was shared openly, starting with a global video conference meeting on 16-17 May 2003 [5]. The measures that were agreed on that basis in May 2003 were: general surveillance of respiratory illnesses; case finding and investigation; triage of persons with febrile illness; selective quarantine; isolation of cases and close contacts of SARS cases; intensive infection control and cleaning in health-care setting and public and professional education (Table 2) [5]. These measures were effective and subsequent reviews indicated that this early sharing and publishing of the results did not prejudice any publications from the countries $[19,20$,$] .$

\section{Conclusions}

It may be concluded that $\mathrm{nCoV}$ requires rapid field research studies combining epidemiological, clinical, serological and virological data to complement the published virological studies. These would be a series of studies carried out around the naturally-occurring cases as was done at speed in 2003 (Table 3) [5,19-26]. An advantage now is the availability of prepared protocols ready for adaptation by the countries that wish to undertake the work [21-25]. Serological techniques have been developed but await both use and validation in the countries experiencing transmission as well as an indication from the International Health Regulations (Article 6) that these and other sorts of studies should be undertaken and the results communicated in a timely manner[3,16,21-27]. 


\begin{tabular}{|c|c|c|}
\hline Parameter & Findings & Implications for control \\
\hline \multirow[t]{3}{*}{ Modes of transmission } & \multirow{2}{*}{$\begin{array}{l}\text { Person-to-person via respiratory route; } \\
\text { Direct (and indirect) contact of mucous } \\
\text { membranes with respiratory secretions, } \\
\text { including fomites; }\end{array}$} & $\begin{array}{l}\text { Strict infection control and respiratory hygiene, } \\
\text { especially in health-care settings; }\end{array}$ \\
\hline & & $\begin{array}{l}\text { Regular and high levels of environmental cleaning } \\
\text { in health-care settings; }\end{array}$ \\
\hline & $\begin{array}{l}\text { Aerosol-generating procedures were } \\
\text { associated with "super-spreading } \\
\text { events" }\end{array}$ & $\begin{array}{l}\text { Avoid aerosol-generating procedures and } \\
\text { undertake scrupulous infection control } \\
\text { procedures when they are essential }\end{array}$ \\
\hline \multirow[t]{3}{*}{ Method of spread } & $\begin{array}{l}\text { Air travel especially important for } \\
\text { international spread; }\end{array}$ & $\begin{array}{l}\text { Persons with febrile respiratory illnesses should } \\
\text { delay travel; }\end{array}$ \\
\hline & \multirow[t]{2}{*}{$\begin{array}{l}\text { Movement of infected patients between } \\
\text { hospitals for local spread }\end{array}$} & $\begin{array}{l}\text { Exit screening for febrile respiratory illness for } \\
\text { those leaving a country where transmission was } \\
\text { taking place regularly; }\end{array}$ \\
\hline & & $\begin{array}{l}\text { Reduction in movement and transfer of certain } \\
\text { patients in complex local health economies }\end{array}$ \\
\hline \multirow[t]{3}{*}{ Those at risk of infection } & $\begin{array}{l}\text { Health care workers } \\
\text { Patients in hospital }\end{array}$ & \multirow{2}{*}{$\begin{array}{l}\text { Particular emphasis on infection control in health } \\
\text { care settings including emergency rooms and } \\
\text { health care waiting rooms }\end{array}$} \\
\hline & Adult family members & \\
\hline & $\begin{array}{l}\text { Children were only rarely infected } \\
\text { themselves or infected others }\end{array}$ & $\begin{array}{l}\text { No reason to take more than the normal } \\
\text { precautions with children }\end{array}$ \\
\hline \multirow[t]{5}{*}{$\begin{array}{l}\text { Setting when infections take } \\
\text { place }\end{array}$} & $\begin{array}{l}\text { Mostly health-care settings including } \\
\text { emergency rooms }\end{array}$ & \multirow{2}{*}{$\begin{array}{l}\text { Particular emphasis on infection control in health } \\
\text { care settings including emergency rooms and } \\
\text { health care waiting rooms }\end{array}$} \\
\hline & \multirow{2}{*}{$\begin{array}{l}\text { Some transmissions in other closed } \\
\text { settings such as aircraft }\end{array}$} & \\
\hline & & \multirow{2}{*}{$\begin{array}{l}\text { Initial triage of febrile patients and those with } \\
\text { respiratory symptoms seeking care }\end{array}$} \\
\hline & \multirow{2}{*}{$\begin{array}{l}\text { Some unusual super-spreading events } \\
\text { in Hong Kong in one hotel and one } \\
\text { apartment complex }\end{array}$} & \\
\hline & & $\begin{array}{l}\text { Avoid aerosol generating procedures and } \\
\text { undertake scrupulous infection control } \\
\text { procedures when they are essential }\end{array}$ \\
\hline Incubation period & 2 to 10 days & $\begin{array}{l}\text { Ten days a reasonable period for quarantine and for } \\
\text { judging whether or not a person was likely to have } \\
\text { SARS if symptomatic and had been in a country } \\
\text { where transmission was taking place regularly }\end{array}$ \\
\hline When infectious & $\begin{array}{l}\text { Low in first few days of symptoms, } \\
\text { maximal in second week }\end{array}$ & $\begin{array}{l}\text { Early self-isolation was found to be especially } \\
\text { effective }\end{array}$ \\
\hline \multirow[t]{2}{*}{ Reproductive number } & Best estimate was $R=1-3$ & \multirow{2}{*}{$\begin{array}{l}\text { Particular emphasis on infection control in health } \\
\text { care settings including emergency rooms and } \\
\text { health care waiting rooms }\end{array}$} \\
\hline & $\begin{array}{l}\text { Most infections did not result in further } \\
\text { infections but super-spreading events } \\
\text { took place }\end{array}$ & \\
\hline Clinical presentation & $\begin{array}{l}\text { Acute, febrile respiratory illness, could } \\
\text { be difficult to notice in persons with } \\
\text { other respiratory illness and post- } \\
\text { operative cases }\end{array}$ & $\begin{array}{l}\text { In a country where transmission was taking place } \\
\text { regularly focus efforts on case-finding among } \\
\text { those with acute, febrile respiratory illness: } \\
\text { so-called fever clinics and initial triage of those } \\
\text { presenting for care to prevent transmission in } \\
\text { waiting areas and emergency rooms }\end{array}$ \\
\hline \multirow[t]{5}{*}{ Effective control measures } & \multicolumn{2}{|l|}{$\begin{array}{l}\text { Intensive surveillance for respiratory } \\
\text { infections and aggressive case finding } \\
\text { where cases were occurring; }\end{array}$} \\
\hline & \multicolumn{2}{|l|}{ Early isolation of putative cases } \\
\hline & \multicolumn{2}{|l|}{ Contact tracing around confirmed cases; } \\
\hline & \multicolumn{2}{|l|}{$\begin{array}{l}\text { Triage of persons with acute febrile } \\
\text { respiratory illnesses }\end{array}$} \\
\hline & \multicolumn{2}{|l|}{$\begin{array}{l}\text { Reduce movement and transfer of } \\
\text { patients }\end{array}$} \\
\hline \multirow[t]{2}{*}{$\begin{array}{l}\text { Those at highest risk of severe } \\
\text { disease }\end{array}$} & $\begin{array}{l}\text { Persons with chronic underlying } \\
\text { conditions; }\end{array}$ & \multirow[t]{2}{*}{ Particular protection of these groups } \\
\hline & Pregnant women & \\
\hline
\end{tabular}


Table 3 Specific public health questions needing answered for the novel coronaviruses - the what, why and how

\begin{tabular}{ll}
\hline $\begin{array}{c}\text { What do we need to } \\
\text { know? }\end{array}$ & $\begin{array}{c}\text { Why do we need to know } \\
\text { it? }\end{array}$ \\
$\begin{array}{l}\text { 1. Where geographically } \\
\text { are the human infections } \\
\text { occurring worldwide? }\end{array}$ & $\begin{array}{l}\text { Determining the level of } \\
\text { threat: is this an infection } \\
\text { only occurring in 1 locality } \\
\text { in 1 sub-region or is it more } \\
\text { widespread? Alternatively } \\
\text { is this an older infection } \\
\text { that has been around } \\
\text { some time and simply } \\
\text { unrecognised? } \\
\text { To inform decisions } \\
\text { on which patients to } \\
\text { test among those who } \\
\text { come to Europe with } \\
\text { respiratory infections or } \\
\text { who subsequently develop } \\
\text { respiratory infections } \\
\text { within a certain time }\end{array}$ \\
\end{tabular}

What is the reservoir of As for point 1 the virus infection?

2. The estimated incubation period (from exposure to symptoms) and serial interval?
Informing on who to test: "all people developing severe acute respiratory infections within a certain number days of coming from countries X, Y, Z"

Determining potential for explosive spread.

Comparing infections like influenza (short incubation period and serial interval: impossible to control) and SARS and smallpox (long incubation period and serial interval: possible to control)
Case-finding virologic testing of people fitting the case definition for severe cases and others;

Prospectively, among the people fitting the Persons Under Investigation (PUI) definitions in any clusters and outbreaks of severe respiratory disease

Serological surveys to agreed protocols with local adaptations [21,22,24].

Applied epidemiological and laboratory research studies in a number of countries testing patients with unexplained severe lower respiratory tract infection, either using retrospective contemporaneous archives of suitable stored specimen or as prospective planned studies.

The ECDC/WHO laboratory survey of European Union countries gives a mechanism by testing people fitting the PUI-with symptoms definition but need to distinguish the different groups therein:

- People with severe disease + geographical risk

- People with severe disease without geographical risk

- Exposed health-care workers

Question: Do we need to know the animal reservoir?

Question: Have Koch's postulates been demonstrated?

Need to think beyond the Middle East and consider the trade/people movements from the Middle East especially migrant workers from South Asia who work in the Middle East

It should be possible to develop the tools but the importance will be validation and quality assurance from the CONSISE and earlier experience. It will be especially important to include validation with 'sticky' sera from middle East countries remembering the initial HIV serological experience where tests developed and validated in one region lost specificity in another setting ${ }^{a}$

Environmental and Environmental and animal studies animal surveillance and testing around sporadic unexplained cases

Observing and investigating clusters to agreed protocols with local adaptations $[21,22]$. 
Table 3 Specific public health questions needing answered for the novel coronaviruses - the what, why and how (concluded)

$\begin{gathered}\text { What do we need to Why do we need to know How will we find out? } \\ \text { know? }\end{gathered}$
it?

3. How infectious are these Informing on infection sources of infectious virus? control measures and their stringency

4. When are these cases infectious to others

5. Are there any superspreading events?

\section{Informing on the} duration of infection control measures and the stringency of control measures, as well as possible advice on quarantine of exposed persons

\section{Informing on infection} control measures and the stringency of control measures cases and what are the

Reviewing the outcome of the case finding around the recognised cases especially in health care staff and household/family contacts

Studies of when and at what levels are the viruses detectable compared to the symptoms and to default cases of influenza and SARS

\section{Reviewing the} outcome of the case finding around the recognised cases especially in health care staff and household/family contacts

6. What do cases look like? Informing on who to Who are the high risk groups? test and understanding the scope of illness manifestations; Understanding the frequencies and severity of organ involvement and secondary bacterial infections to assist in clinical management

\section{Review of the} confirmed cases; Serological testing of contacts, especially symptoms, and virologic testing of contacts exposed in future events [21]. those with milder
In SARS most cases did not transmit to secondary cases, but $10 \%-20 \%$ transmitted to many secondary (and higher order) cases: super-spreading events $[7,19,20]$.

There are some data from this from Germany (Robert Koch Institute). Note: a positive feature of SARS was that the cases were really not infectious before developing symptoms (c.f. influenza) making quarantine and early isolation of cases especially effective [5].

Watch for these especially in healthcare settings. What actually happened in the clusters in Jordan and Saudi Arabia?

Note: a problem with SARS was that infectious cases were not always recognised in a timely manner. Some were inapparent for example in those hospitalised for other reasons (e.g. post major surgery, people with multiple pathology). In a sense this has happened in the cases that were imported into Germany and the United Kingdom without thinking they might represent serious imported infections.

Suitable protocols have now been agreed between ISARIC members and approved by WHO [25].

Preparing and
agreeing protocols,
and those caring for
patients applying
these and sharing
experience and results
in real time

WHO Member States asking the referral centre;

Work with people who look at transport trends and patient export importations
Note for the cases that came to other countries the long time between the arrival and considering testing for novel infections.
Considering the risk to

those caring for patients in transit
Looking for cases and determining which Middle East to Europe?
To optimise care and to avoid doing harm from certain medical interventions

${ }^{a}$ When HIV serological tests validated in Europe and North America were applied in Africa in the 1980s without local validation and the consequent publication of analyses suggesting substantial levels of population prevalence in East Africa which were due to cross-reaction with other antibodies (to malaria) [26]. $E C D C=$ European Centre for Disease Prevention and Control.

$W H O=$ World Health Organization.

CONSISE = consortium for the standardization of influenza seroepidemiology.

$H I V=$ human immunodeficiency virus.

SARS = severe acute respiratory syndrome.

ISARIC = International Severe Acute Respiratory and Emerging Infection Consortium. 


\section{References}

1. Rapid risk assessment: severe respiratory disease associated with a novel coronavirus, 19 February 2013. Stockholm, European Centre for Disease Prevention and Control, 2013 (http://ecdc.europa.eu/en/publications/Publications/novel-coronavirus-rapid-risk-assessment-update.pdf, accessed 11 May 2013).

2. Danielsson N, on behalf of the ECDC Internal Response Team. Catchpole M. Novel coronavirus associated with severe respiratory disease: Case definition and public health measures. Eurosurveillance, 2012, 17(39):pii 20282.

3. Heymann D, Mackenzie J, Peiris M. SARS legacy: outbreak reporting is expected and respected Lancet, 2013, 381(9869):779-781.

4. Eurosurveillance editorial team. Note from the editors: A new virus bringing back memories from the past. Eurosurveillance, 2012, 17(39):pii 20284.

5. Consensus document on the epidemiology of severe acute respiratory syndrome. Geneva, World Health Organization, Department of Communicable Disease Surveillance and Response 2003 (WHO/CDS/CSR/GAR/2003.11) (http://www.who.int/ csr/sars/en/WHOconsensus.pdf, accessed 11 May 2013).

6. Health Protection Agency (HPA) UK, Novel Coronavirus Investigation team. Evidence of person-to-person transmission within a family cluster of novel coronavirus infections, United Kingdom, February 2013. Eurosurveillance, 2013;18(11): pii 20427

7. Update: Outbreak of Severe Acute Respiratory Syndrome - Worldwide, 2003. Morbidity and Mortality Weekly Report (MMWR), 2003, 52(12):241-248.

8. Genetic sequence information for scientists about the novel coronavirus 2012. Whole Genome Sequence - Added 18th February 2013. London, Public Health England, Health Protection Agency 2013 (http://www.hpa.org.uk/Topics/InfectiousDiseases/InfectionsAZ/NovelCoronavirus2012/ respPartialgeneticsequenceofnovelcoronavirus/) accessed 11 May 2013.

9. Cotten $\mathrm{M}$ et al. Full-genome deep sequencing and phylogenetic analysis of novel human betacoronavirus. Emerging Infectious Diseases, 2013, 19(5) (http://wwwnc.cdc.gov/eid/ article/19/5/13-0057_article.htm, accessed 11 May 2013).

10. Annan A et al. Human betacoronavirus 2c EMC/2012-related viruses in bats, Ghana and Europe.[Internet]. Emerging Infectious Diseases, 2013, 19:456-459.

11. Raj VS et al. Dipeptidyl peptidase 4 is a functional receptor for the emerging human coronavirus-EMC. Nature, 2013, 495:251254 (http://www.nature.com/nature/journal/v495/n7440/ pdf/nature12005.pdf, accessed 11 May 2011).

12. Chan JP et al. Differential cell line susceptibility to the emerging novel human betacoronavirus 2c EMC/2012: implications on disease pathogenesis and clinical manifestation. Journal of Infectious Diseases. (2013) 207(11):1743-1752.

13. Müller $\mathrm{M}$ et al. Human coronavirus EMC does not require the SARS-coronavirus receptor and maintains broad replicative capability in mammalian cell lines. mBio, 2012, 3(6) (http:// mbio.asm.org/content/3/6/e00515-12.long, accessed 11 May 2013).

14. Mackintosh K. A new virulent human coronavirus: How much does tissue culture tropism tell us? Journal of Infectious Diseases (Advance Access), 2013 (http://jid.oxfordjournals.org/con- tent/early/2013/03/24/infdis.jit125.full.pdf+html, accessed 11 May 2013).

15. Li W et al. Bats are natural reservoirs of SARS-like coronaviruses. Science, 2005, 310:676-679.

16. Buchholz $U$ et al. Contact investigation of a case of human novel coronavirus infection treated in a German hospital, October-November 2012. Eurosurveillance, 2013, 18(8):20406 (http://www.eurosurveillance.org/ViewArticle. aspx?Articleld=20406, accessed 11 May 2013).

17. Pebody RG et al. The United Kingdom public health response to an imported laboratory confirmed case of a novel coronavirus in September 2012. Eurosurveillance, 2012, 17(40):pii 20292.

18. Summary of probable SARS cases with onset of illness from 1 November 2002 to 31 July 2003 (Based on data as of the 31 December 2003.). Geneva, World Health Organization, Global Health and Response, 2003 (http://www.who.int/csr/sars/ country/table2004_04_21/en/index.html, accessed 11 May 2013).

19. Anderson RM et al. Epidemiology, transmission dynamics and control of SARS: the 2002-2003 epidemic. Philosophical Transactions of the Royal Society of London. Series B, Biological Sciences, 2004, 359:1091-1105.

20. Peiris JS et al. The severe acute respiratory syndrome. New England Journal of Medicine, 2003, 349:2431-2441.

21. "The First Few Hundred (FF100)" Enhanced Case and Contact Protocol v4.0. Epidemiological protocols for comprehensive assessment of early novel coronavirus cases and their close contacts in the United Kingdom. London, Health Protection Agency, 2012 (http://www.hpa.org.uk/webc/HPAwebFile/ HPAweb_C/1317136300809, accessed 11 May 2013).

22. Van Kerkhove $M$ et al. on behalf of the CONSISE steering committee. The consortium for the standardization of influenza seroepidemiology (CONSISE): a global partnership to standardize influenza seroepidemiology and develop influenza investigation protocols to inform public health policy. Influenza and Other Respiratory Viruses, 2012, 7(3).

23. Reusken $\mathrm{C}$ et al.Specific serology for emerging human coronaviruses by protein microarray.Eurosurveillance, 2013, 18:pii 20441.)

24. Van Kerkhove M. CONSISE and avian influenza H7N9. CONSISE Working Draft Protocols for influenza. London, CONSISE The Consortium for the Standardization of Influenza Seroepidemiology, 2013 (http://consise.tghn.org/articles/consise-andavian-influenza-h7n9/, accessed 11 May 2013).

25. Longuère K-S. ISARIC and WHO SARI and Natural History Protocols. Oxford, ISARIC (International Severe Acute Respiratory and Emerging Infection Consortium), 2013 (http://isaric.tghn. org/articles/isaric-and-who-sari-and-natural-history-protocols/, accessed 11 May 2013).

26. Biggar RJ et al. Regional variation in prevalence of antibody against human T-lymphotropic virus types I and III in Kenya. East Africa International Journal of Cancer, 1985, 35(6):763-767 (http://onlinelibrary.wiley.com/doi/10.1002/ ijc.2910350611/abstract, accessed 11 May 2013).

27. International Health Regulations, 2005, 2nd ed. Geneva, World Health Organization, 2008 (http://whqlibdoc.who.int/publications/2008/9789241580410_eng.pdf, accessed 11 May 2013). 